\title{
Alkusanat toimittajilta
}

\author{
Maija Aksela \& Lauri Vihma \\ LUMA-keskus Suomi \& Helsingin yliopisto
}

Vuodesta 2004 lähtien järjestetyt Valtakunnalliset LUMA-päivät järjestettiin ensimmäistä kertaa Joensuussa 1.-3.6.2015. Päivät järjestettiin ensimmäistä kertaa myös uutena ajankohtana, kesäkuun alussa heti koulutyön kesäkeskeytyksen alettua. Tapahtuma oli ensimmäistä kertaa myös kolmipäiväinen, laajan ohjelmatarjonnan vuoksi. LUMA-päiville osallistui kaikkiaan kolmesataa LUMA-opetusalan nykyistä tai kasvavaa asiantuntijaa varhaiskasvatuksesta korkeakouluihin: opettajia, opettajaksi opiskelevia, opettajankouluttajia, opetuksen tutkijoita ja opetuksen kehittäjiä Suomesta ja ulkomailtakin. Tapahtuman teemoina olivat uudistuvat opetussuunnitelmien perusteet, digitalisoituvat oppimisympäristöt ja arviointi sekä Kansainvälinen valon vuosi 2015. Osa ohjelmasta oli englanniksi tapahtuman yhteydessä järjestetyn kansainvälisen ISSE 2015 symposiumin osallistujia varten.

Ohjelmaan kuului LUMA-keskus Suomen johdon ja Itä-Suomen yliopiston tervehdykset osallistujille, viisi luentoa, kaksi paneelikeskustelua sekä kymmeniä tietoiskuja ja työpajoja. Keynote-luennoitsija oli Stanfordin yliopiston professori Jonathan Osborne, joka puhui opetussuunnitelman uudistuksista yhdysvaltalaisesta näkökulmasta. Paneelikeskusteluissa asiantuntijat opetushallinnosta, yliopistoista ja kustannusalalta pohtivat uudistuvien opetussuunnitelmien sekä digitaalisten oppimisympäristöjen ja digitaalisen arvioinnin käyttöönoton mahdollisuuksia ja haasteita. Tietoiskuja/työpajoja oli $\mathrm{mm}$. reilusta kolmestakymmenestä LUMA SUOMI -ohjelmaan kuuluvasta kehittämishankkeesta, lisäksi kansallisten Scientix-lähettiläiden sekä useiden muiden asiantuntijoiden vetäminä. Tähän teemanumeroon pyydettiin kaikilta päivien esiintyjiltä kirjoitukset. Numeroon on koottu saapuneita, tietoiskuja tai työpajoja vetäneiden asiantuntijoiden artikkeleita hankkeistaan tai erityisalastaan LUMA-aineiden opetuksen näkökulmasta. Seuraavat valtakunnalliset LUMA-päivät järjestetään Lahdessa (6.-8.6.2016) ja Jyväskylässä (5.-7.6.2017).

Oivaltamisen ja onnistumisen iloa matematiikasta, luonnontieteistä ja teknologiasta! 